\title{
Streptococcus mutans Group
}

National Cancer Institute

\section{Source}

National Cancer Institute. Streptococcus mutans Group. NCI Thesaurus. Code C86798.

A bacterium that belongs to the Mutans group of the genus Streptococcus. 